\title{
Contribuições do Papa Francisco para o diálogo inter-religioso: um tópico a aprofundar a partir dos discursos do Papa Francisco em suas viagens internacionais
}

\author{
Orientadora: Profa. Maria Teresa de Freitas Cardoso \\ Pesquisador: José Ronaldo Venâncio dos Santos \\ Fonte: $\mathrm{CNPq}$
}

\section{Introdução}

Nesta pesquisa iremos abordar o diálogo inter-religioso a partir do pontificado do Papa Francisco, em especial em seus discursos em suas viagens internacionais, buscaremos elencar pensamentos e vertentes até os dias atuais, tomando sua exortação apostólica Evangelii Gaudium como um dos documentos mais importantes para ponto de partida desta temática. A Exortação Evangelii Gaudium nos convida a sermos uma Igreja em saída. Desse modo, esse documento nos convoca para irmos em frente e tomarmos iniciativas sem medo, indo ao encontro do outro, apoiando-nos no diálogo e através dele chegarmos a uma só comunidade, pois todos têm a mesma origem em Deus, como se acenava na Declaração Nostra Aetate (n.1).

O Santo Padre, o Papa, propõe o diálogo como especial forma de caminhar na dimensão do Evangelho e, sequencialmente, apresenta o diálogo inter-religioso como traço importante de evangelização para a Igreja em nosso tempo. Nessa direção, o diálogo inter-religioso implica partilha de vida, experiência e conhecimento. Assim, para esse diálogo acontecer se faz necessário que cada um esteja enraizado em sua fé específica, como também disponível ao aprendizado da diferença neste mundo plural. Esta temática aparece nas viagens do Papa Francisco e será tratada na pesquisa que desenvolvemos.

Fica evidente que o Papa Francisco é a favor do diálogo inter-religioso e que em todas as suas viagens ele aborda a importância desse assunto, pois o Papa, ainda por ocasião do evento da Jornada Mundial da Juventude (JMJ), 
quando ocorrido no Brasil, referiu que se deve ser favorável à pacífica convivência entre religiões diversas e a laicidade do Estado que, sem assumir como própria qualquer posição confessional, respeita cada uma delas e valoriza a sua presença e a dimensão religiosa na sociedade, favorecendo as suas expressões mais concretas.

\section{Objetivos}

Um objetivo é mostrar temas levantados na Evangelii Gaudium e nos discursos do Papa Francisco sobre as condições atuais, os maiores desafios e as perspectivas religiosas cristãs ou de outras tradições religiosas, vistos em suas viagens internacionais por ocasião das Jornadas Mundiais da Juventude e sugestões para o diálogo. No projeto inicial se buscava o conjunto das viagens, porém se constatou a necessidade de se fazer, nesse período da pesquisa, uma seleção dentre os discursos, para mais aprofundamento. Optou-se por uma concentração nas viagens de JMJ, dada a importância das mesmas para o desenvolvimento dos diálogos em nosso tempo. A pesquisa das outras viagens ficou prevista para uma segunda etapa de estudos no tema.

Outro objetivo é identificar as principais contribuições do Papa Francisco para os temas de Diálogo inter-religioso e de solidariedade, que cooperem para as questões sistemático-pastorais sobre a Igreja e os diálogos, segundo a vocação e missão da Igreja. 